\title{
Content identification for the development of a nutrition resource kit for malnourished and at-risk elderly: A review
}

\author{
Iman Nabihah Noor Azam ${ }^{1}$, Aliza Haslinda Hamirudin ${ }^{1 *}$, Sakinah Harith ${ }^{2}$, \\ Mohd Aznan Md Aris ${ }^{3}$, Karimah Hanim Abd Aziz ${ }^{4}$, Siti Nur Amirah Sheikh \\ Hishamuddin $^{1}$ \& Nurul Syaireen A Rashid ${ }^{5}$
}

${ }^{1}$ Department of Nutrition Sciences, Kulliyyah of Allied Health Sciences, International Islamic University Malaysia, Pahang, Malaysia; ${ }^{2}$ School of Nutrition and Dietetics, Faculty of Health Sciences, Universiti Sultan Zainal Abidin, Terengganu, Malaysia; ${ }^{3}$ Department of Family Medicine, Kulliyyah of Medicine, International Islamic University Malaysia, Pahang, Malaysia; ${ }^{4}$ Department of Community Medicine, Kulliyyah of Medicine, International Islamic University Malaysia, Pahang, Malaysia; ${ }^{5}$ Primary Health Care Unit, Pahang Health State Department, Bandar Indera Mahkota, Pahang, Malaysia

\begin{abstract}
Introduction: Elderly population is more likely to suffer from malnutrition, thereby requiring appropriate nutrition education as part of nutrition intervention to overcome this issue. This review aims to identify content suitable for developing a nutrition resource kit that provides nutritional guidance to combat malnutrition among malnourished and at-risk elderly in health clinics setting, particularly in Malaysia. Methods: A literature search was conducted up to $15^{\text {th }}$ December 2019 in four databases: PubMed, Scopus, COCHRANE, and ProQuest Health \& Medical Collection. Potential literature on nutrition education, suitable dietary guidelines and existing educational materials for elderly in the community, in English and Malay languages, were searched to identify suitable content for the nutrition resource kit. All relevant documents were included based on inclusion and exclusion criteria. Data were extracted and analysed according to the PRISMA-ScR guidelines. Results: A total of 27 documents consisting of articles, printed materials and guidelines were included for analysis. Suitable content included information related to malnutrition such as definition, signs and symptoms, cause-consequences, and nutrition management, which included food plate, serving size, menu suggestion, examples of recipes, tips to increase energy and protein intakes through food or drink, texture modification, a guide to using oral nutritional supplements, tips for maintaining nutrient content in food and drink, tips to encourage to eat, and oral health. Conclusion: A nutrition resource kit tailored for malnourished and at-risk elderly would be a beneficial nutrition intervention. There is a need to incorporate these information in the development of a nutrition resource kit to improve their dietary intake.
\end{abstract}

Keywords: malnutrition, elderly, community, nutrition education, scoping review

\footnotetext{
*Corresponding author: Dr. Aliza Haslinda Hamirudin

Department of Nutrition Sciences, Kulliyyah of Allied Health Sciences

International Islamic University Malaysia, Jalan Sultan Ahmad Shah, 25200 Kuantan, Pahang, Malaysia

Tel: (6)09-5716400 Ext 3370; Fax: (6)09-5716776; E-mail: aliza@iium.edu.my

doi: https://doi.org/10.31246/mjn-2020-0118
} 


\section{INTRODUCTION}

The number of elderly worldwide continues to grow. According to United Nations estimates, the elderly population aged 60 years and above is expected to reach nearly 1.4 billion in 2030, 2.1 billion in 2050, and 3.1 billion in 2100 (United Nations, 2017). In Malaysia, recent data show that the percentage of Malaysian elderly increased from $6.5 \%$ in the year 2018 to $6.7 \%$ in the year 2019 (Department of Statistics Malaysia, 2019).

The elderly population is susceptible to suffering from malnutrition due to numerous factors, such as eating difficulties (Mann, Heuberger \& Wong, 2013), depressive symptoms, poor functional status and lifestyle factors (Van Bokhorst-de van der Schueren et al., 2013), as well as socioeconomic changes (Damiao et al., 2017). The prevalence of malnutrition among the elderly differs according to the setting. A systematic review and meta-analysis of 240 studies by Cereda et al. (2016) reported a range of 3 to $29 \%$ for the prevalence of malnutrition among elderly in different types of settings. In the community, the pooled prevalence of high malnutrition risk across European countries was reported to be $8.5 \%$ using various malnutrition screening tools (LeijHalfwerk et al., 2019). Similarly, $1.3 \%$ to $36.3 \%$ and $25.3 \%$ to $48.5 \%$ of Malaysian elderly living in the community were found to be malnourished and at-risk, respectively, as reported in a systematic review by Zainudin et al. (2016). Meanwhile, $48 \%$ to $55 \%$ of hospitalised elderly were reportedly malnourished in Malaysia (Nur Fazimah, Sakinah \& Rosminah, 2013).

In order to overcome this multifactorial issue, nutrition education is an important part of nutrition intervention to improve dietary intake. Nutrition experts are recommended to provide information and education to malnourished and at-risk elderly in order to enhance their nutritional awareness and knowledge (Volkert et al., 2019). Thus, providing a nutrition resource kit tailored for them would be a useful form of nutrition education (Hamirudin et al., 2014), which could directly improve the nutrition knowledge of the elderly population. Higgins and Barkley (2004) also mentioned that the use of printed and other educational materials is effective in increasing the awareness and knowledge of elderly. Additionally, studies globally and locally have demonstrated the use of nutrition resource in delivering nutritional guidance for the elderly (Schoberer et al., 2018; Shahar et al., 2012; Yahya et al., 2020). However, these materials were not specifically made for the atrisk and malnourished elderly. They were developed for the general elderly population to prevent and overcome common nutritional problems among the elderly, including malnutrition. Hence, developing and providing a nutrition resource kit tailored specifically for the at-risk and malnourished elderly group is warranted to improve their nutritional status.

In view of this, the content or outline of the kit should be identified before proceeding to the proper development of a nutrition resource kit. To the best of our knowledge, there is still a lack of comprehensive content and discussion about suitable content that could be incorporated into a nutrition resource kit for malnourished and at-risk elderly. A comprehensive content is needed to ensure all the necessary and important information are included to improve the elderly's nutritional knowledge, dietary intake, and nutritional status. Hence, this scoping review aims to identify suitable content for future development of a nutrition resource kit 
for malnourished and at-risk elderly who receive primary care services in the Malaysian health clinics setting. Appropriate and suitable information that could contribute to malnutrition prevention and management among the elderly are essential to improve their nutritional status and health outcomes.

\section{MATERIALS AND METHODS}

\section{Data source}

This scoping review employed the Preferred Reporting Items for Systematic and Meta-Analyses extension for Scoping Reviews (PRISMA-ScR), which was performed up to $15^{\text {th }}$ December 2019. Four online databases (PubMed, Scopus, COCHRANE, and ProQuest Health \& Medical Collection) were searched with no restrictions on publication date to identify potential literature related to nutrition education for the elderly in community settings. In addition, a manual search was performed for suitable guidelines and educational materials to supplement the database search. A manual search can be described as an additional approach to database searches in order to identify additional documents for review (Vassar, Atakpo \& Kash, 2016). The search terms used for this review are shown in Box 1 .

\section{Selection of studies}

The study's inclusion and exclusion criteria were determined before the search. Studies included were the ones with (1) elderly aged 60 years old and above; (2) community setting; (3) documents written in English and Malay languages; and (4) full text only. Exclusion criteria included studies that involved (1) hospital setting; (2) medical conditions that required specific nutrition intervention; and (3) animal, nutrients or biomarkers studies. Articles that were not relevant to the specified criteria were excluded.

\section{Data extraction, quality assessment, data synthesis and analysis}

The author(s), title, year of publication, setting, study design, study objective, details of nutrition education, and findings were extracted from the reviewed studies. Selected relevant articles were further assessed for their level of evidence and study quality. The level of evidence was identified according to the rating scheme for Level of Research Evidence by Ackley et al. (2008), in which Level I is considered as the highest level of evidence consisting of systematic reviews and meta-analysis, while Level VII is the lowest level of evidence consisting of expert opinion or report. Providing information on the level of evidence would be beneficial for readers to prioritise these information.

Meanwhile, the study quality was determined by using the available study quality assessment tool and was

Box 1. Search terms used in the review

(malnutrition OR undernutrition OR undernourished OR malnourished) AND (elder* OR geriatric OR senior* OR “older adult*" OR “old* people” OR aging OR ageing) NOT (children OR youth OR infant* OR pediatric OR paediatric OR adolescent*) AND community OR "health clinic*" OR clinic* OR outpatient OR "primary care" OR "general practice") NOT (ward* OR inpatient OR hospital*) AND ("diet* education" OR "nutrition* education" OR education* OR "health education" OR "food guide" OR "health promotion" OR "education* module*" OR "health information" OR "education* model*" OR "nutrition* module* OR "nutrition* resource*” OR "nutrition* education* package*”) 
rated as good, fair or poor based on the judgement of two researchers. Two researchers independently assessed the study quality, and any inconsistency was resolved through discussion and agreement with other researchers. For cross-sectional and controlled intervention studies, the National Heart,

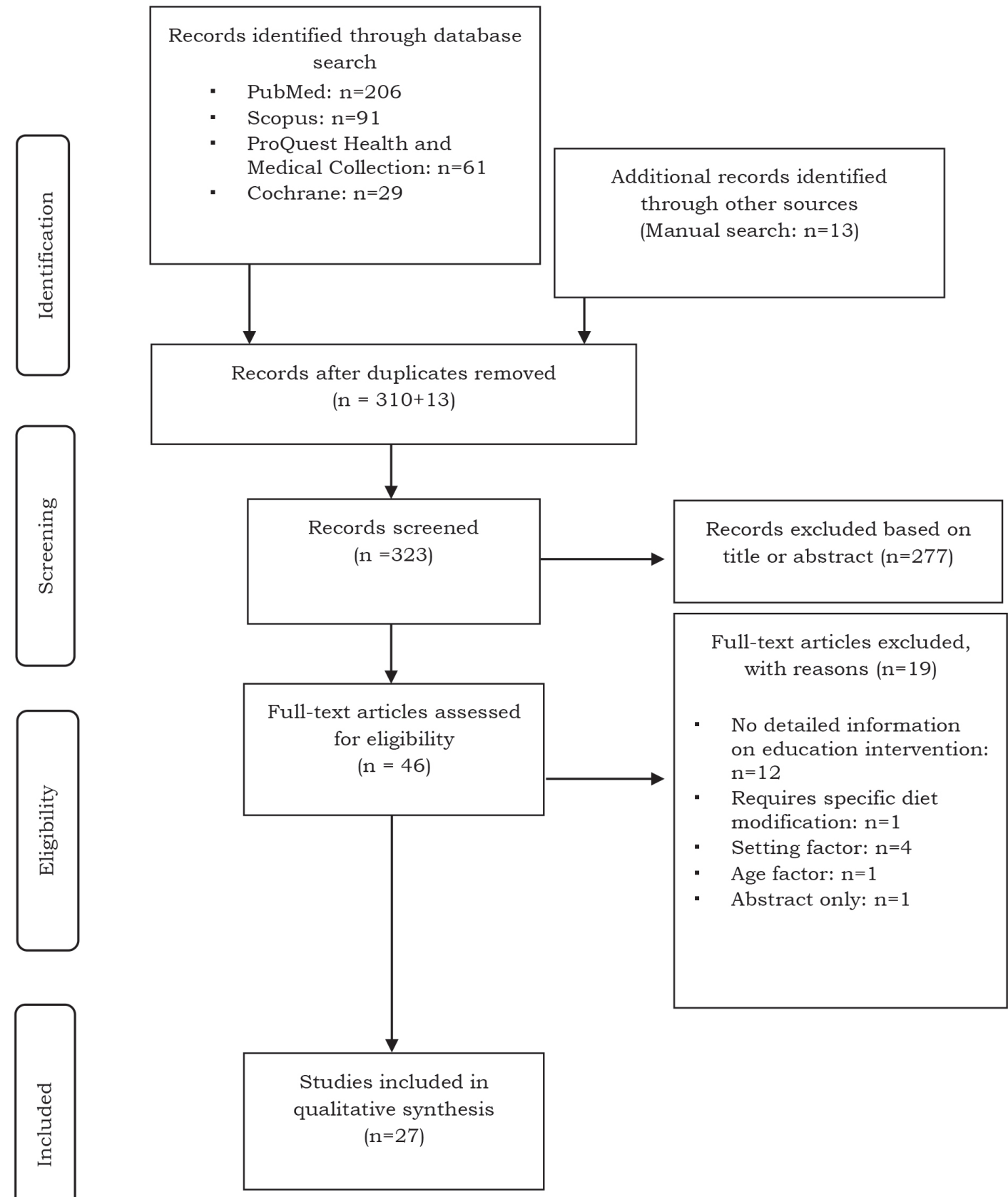

Figure 1. Study selection process for scoping review 
Lung and Blood Institute (NLHBI) study quality assessment tool was used to rate the study quality. Qualitative and mixed-method studies were rated using the Critical Appraisal Skills Programme (CASP) checklist. For discussion paper and case report, they were not applicable to be rated for study quality. Currently, only the Joanna Briggs Institute (JBI) provides a critical appraisal checklist for these types of papers. So, it was used as a checklist for the papers to be included in the review.

Any information in the selected documents that could serve as topics in a nutrition resource kit were extracted. The information were listed as potential topics and discussed among the research team members before finalising the content of the nutrition resource kit.

\section{RESULTS}

\section{Overview of studies identified}

The process of identifying relevant studies is summarised in Figure 1. Electronic searches via online databases retrieved 487 articles and 13 documents from a manual search were found to be potentially relevant to the present scoping review. After duplicates were removed, a total of 323 records were screened thoroughly for relevant abstracts. This resulted in 47 records that were reviewed against the inclusion and exclusion criteria. Finally, 14 papers which consisted of seven controlled intervention studies, three cross-sectional studies, two mixedmethod studies, once case report, and one discussion paper were selected. Overall, 27 records consisting of articles, printed materials and guidelines that met the criteria were included for this review. The level of evidence among these studies ranged from level II to level VII, which were of fair and good quality.

The results were summarised and tabulated in tables. Tables 1 and 2 indicate the summary of the outline or topics that can be included in a nutrition resource kit. Tables 3 and 4 mainly display the nutritional requirements for elderly, particularly for malnourished and at-risk populations, and act as references for content development. Meanwhile, Table 5 displays the summary of topics suitable to be included in the nutrition resource kit. In general, the suitable content was categorised into three components; 1) understanding malnutrition; 2) managing malnutrition; and 3) implementing malnutrition management, which will be explained below.

\section{Content in nutrition resource kit}

\section{Understanding malnutrition}

This review identified that general information related to malnutrition were given to the elderly and caregivers to ensure their understanding of the issue. The information provided to the target population included definition, signs and symptoms, as well as causes and consequences (Fernández-Barrés et al., 2017; van Doorn-van Atten et al., 2018). These kind of information would provide new insights for the elderly, which may directly increase their awareness of malnutrition issues.

\section{Managing malnutrition}

Management of malnutrition including information on macronutrient and fluid requirements, and serving size or exchange should also be considered as content in a nutrition resource kit. Generally, most studies provided tailored and non-tailored information on the needs for adequate intake of macroand micronutrients among elderly participants in order to prevent and overcome malnutrition (Ahmadzadeh Tori et al., 2019; Brooke \& Ojo, 2015; Endevelt et al., 2011; FernándezBarrés et al., 2017; Luger et al., 2016; 


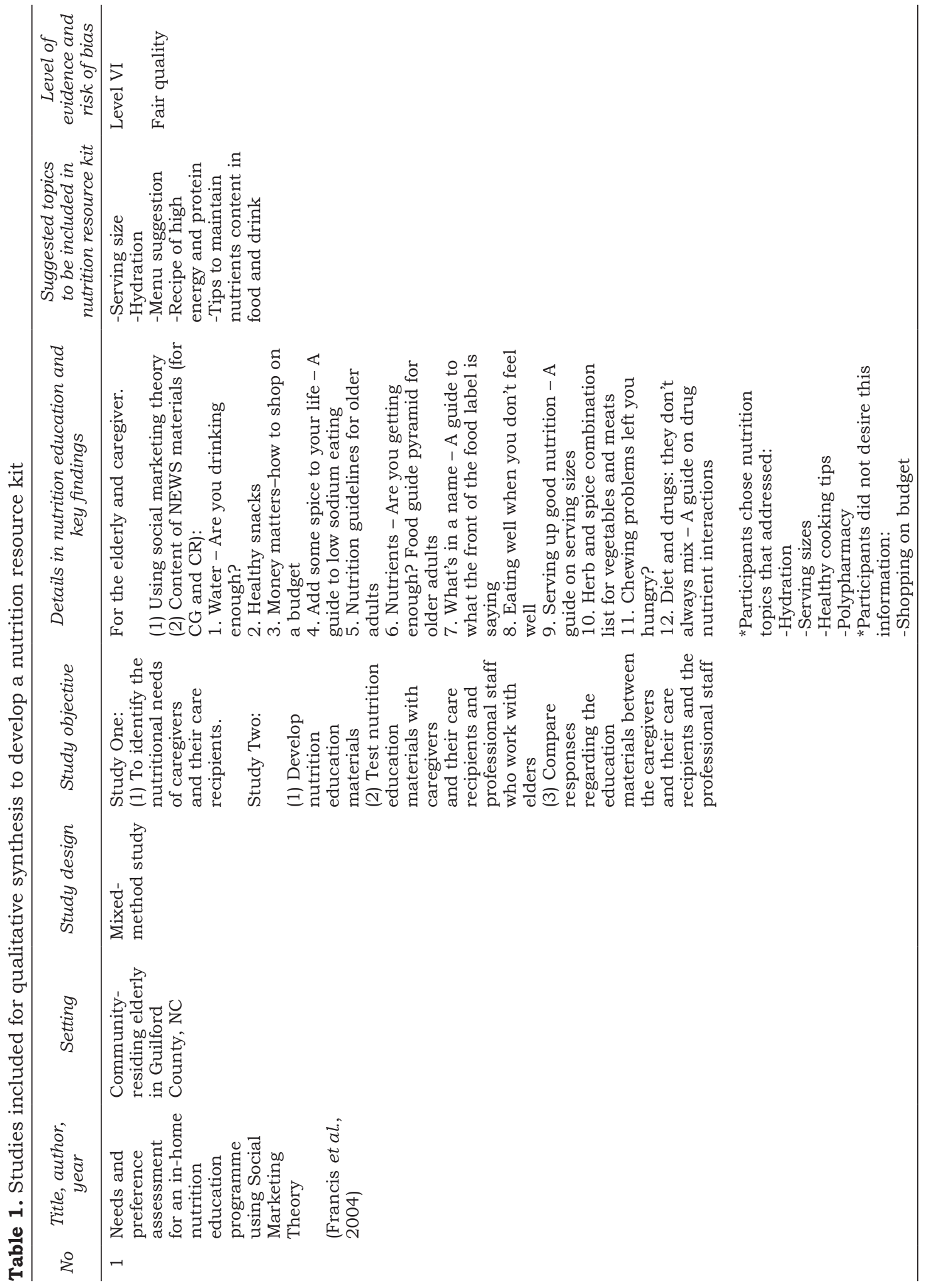




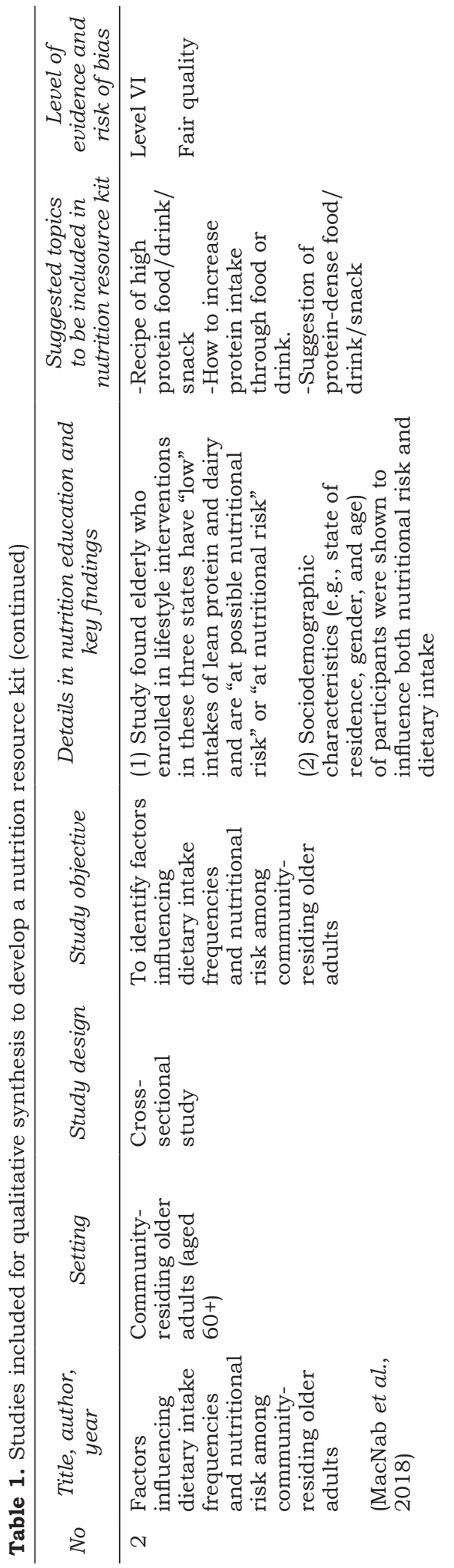

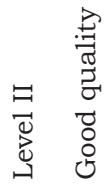

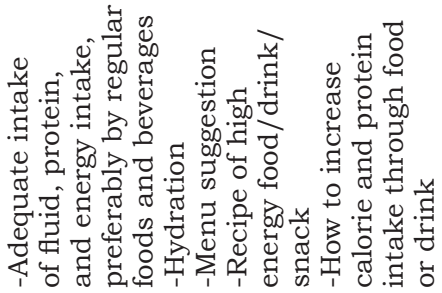

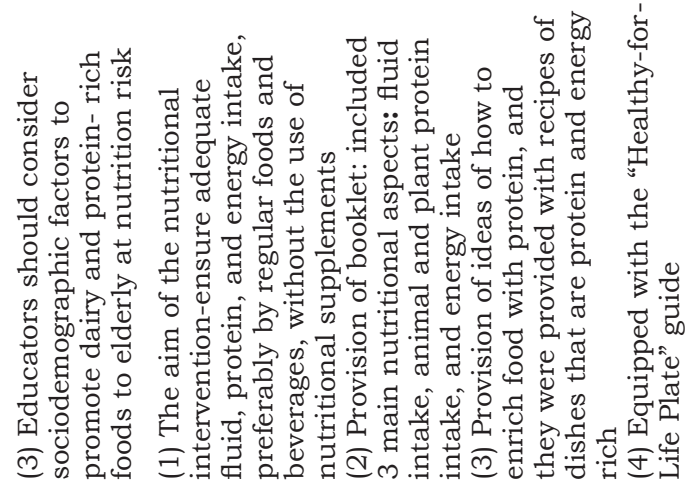

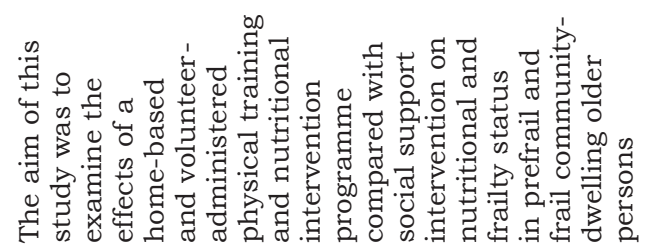

豕

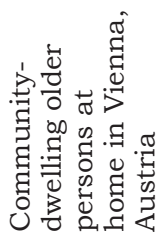

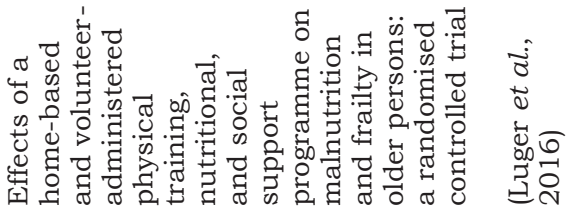

$m$ 


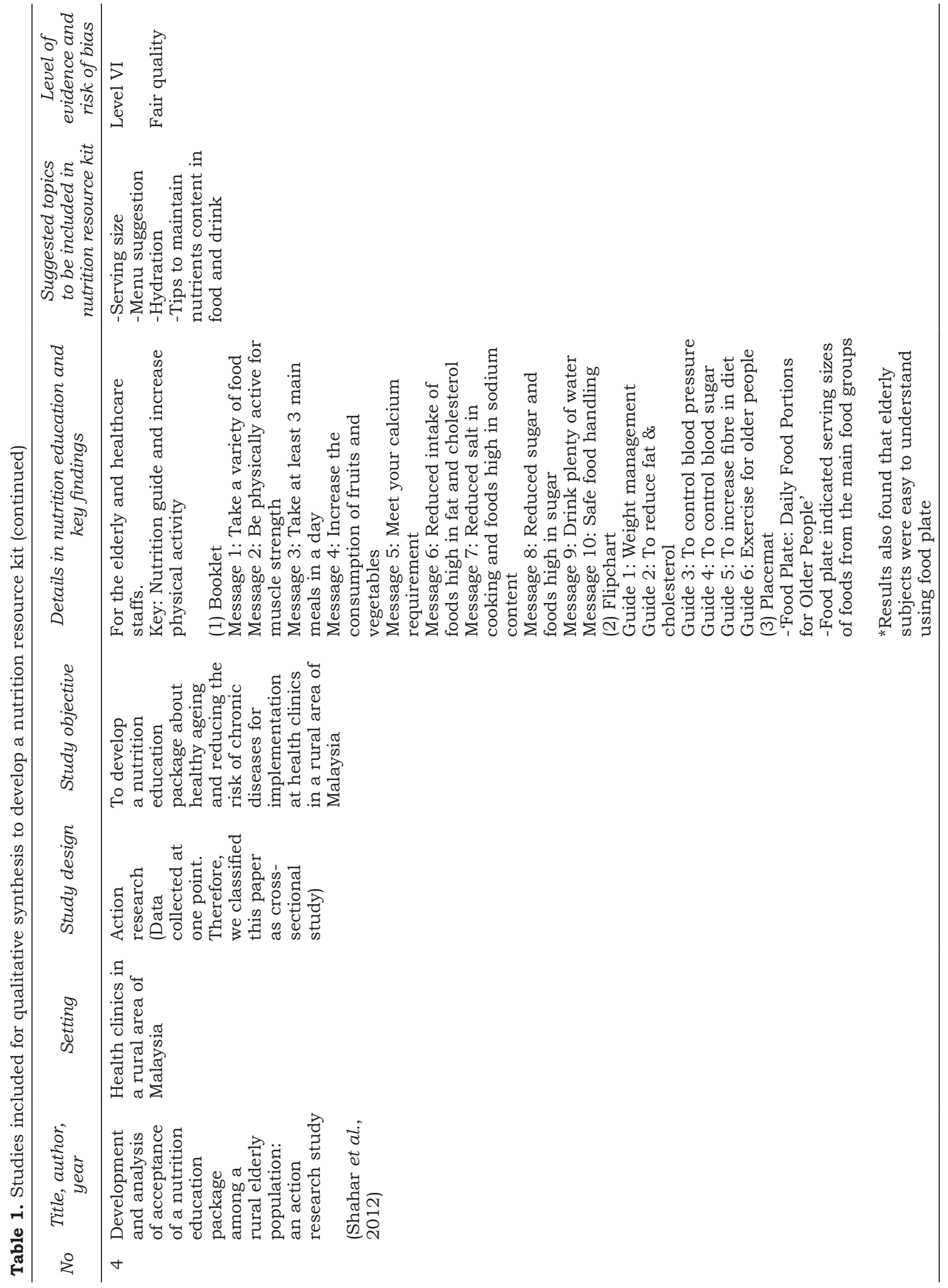




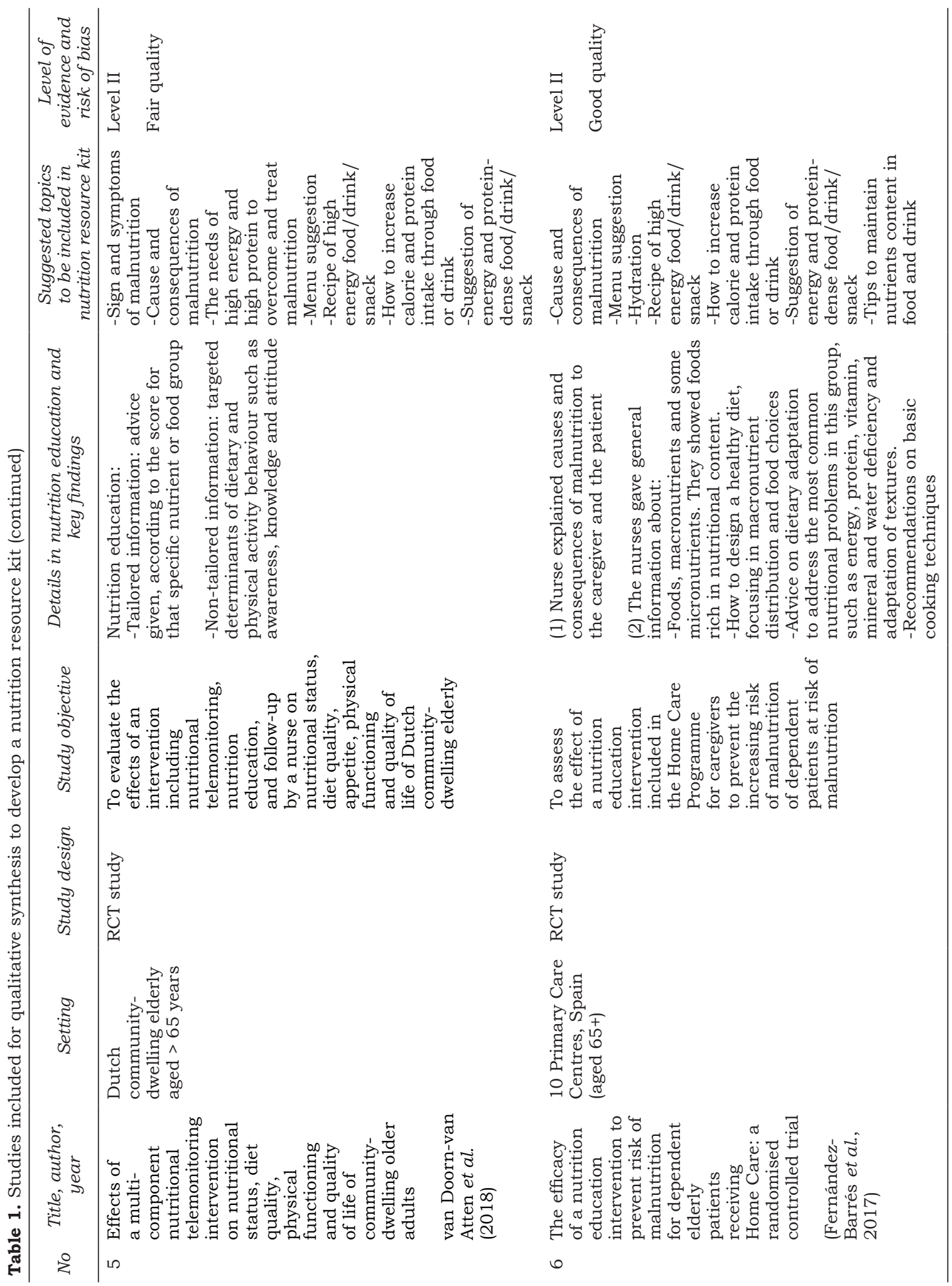




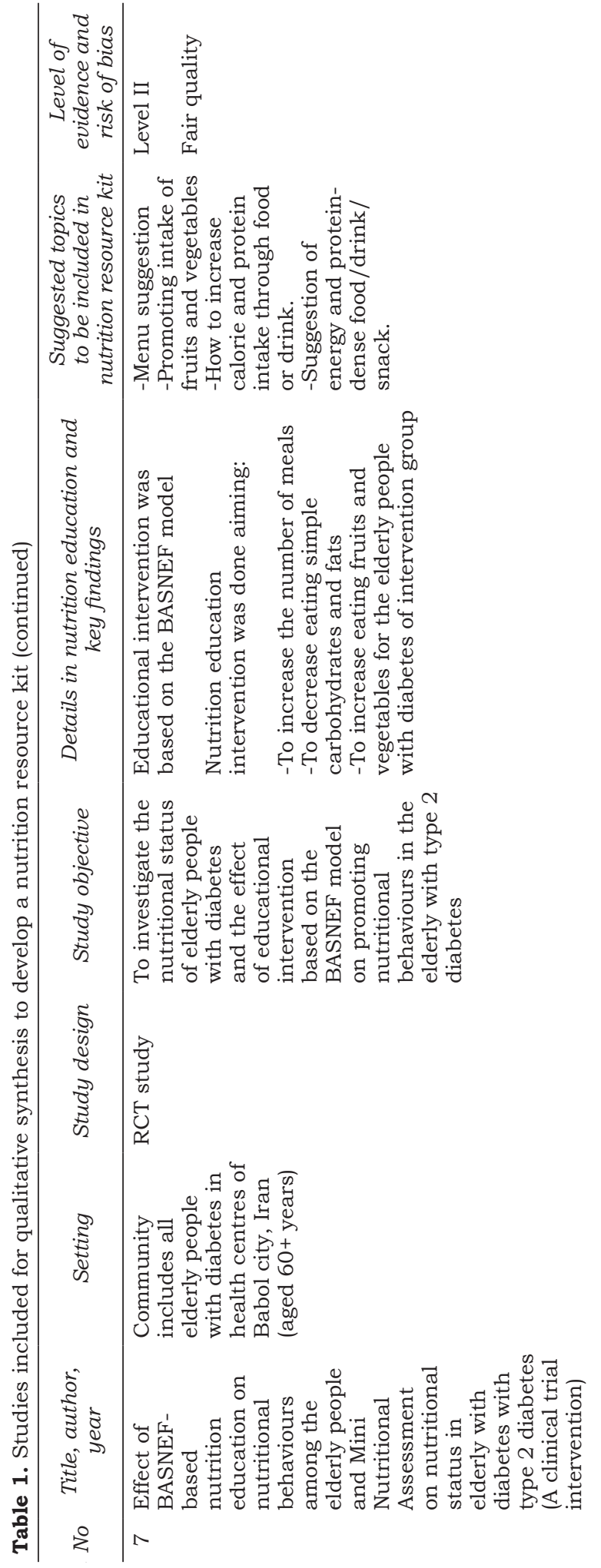

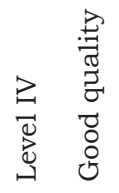
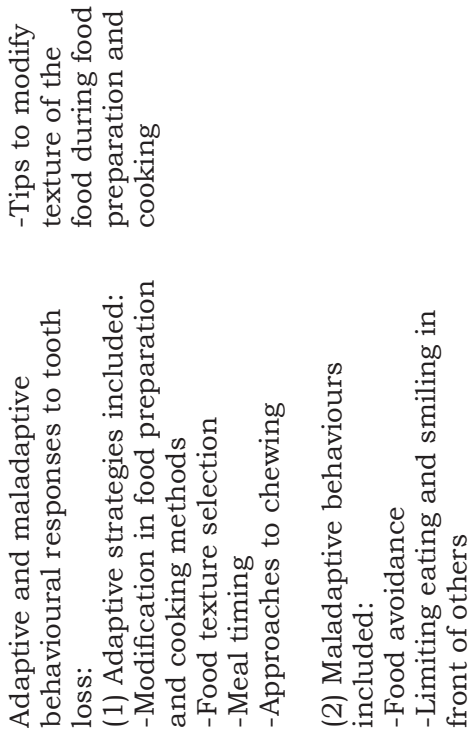

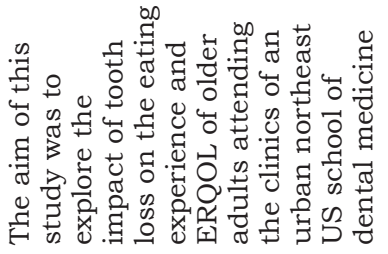

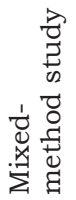

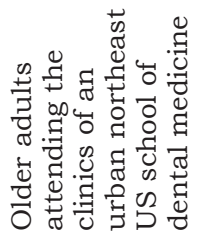

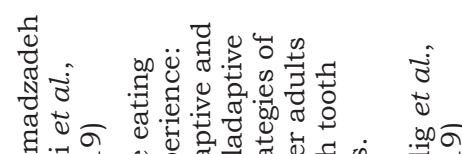

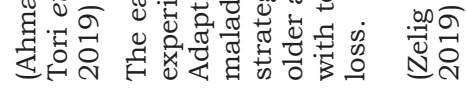




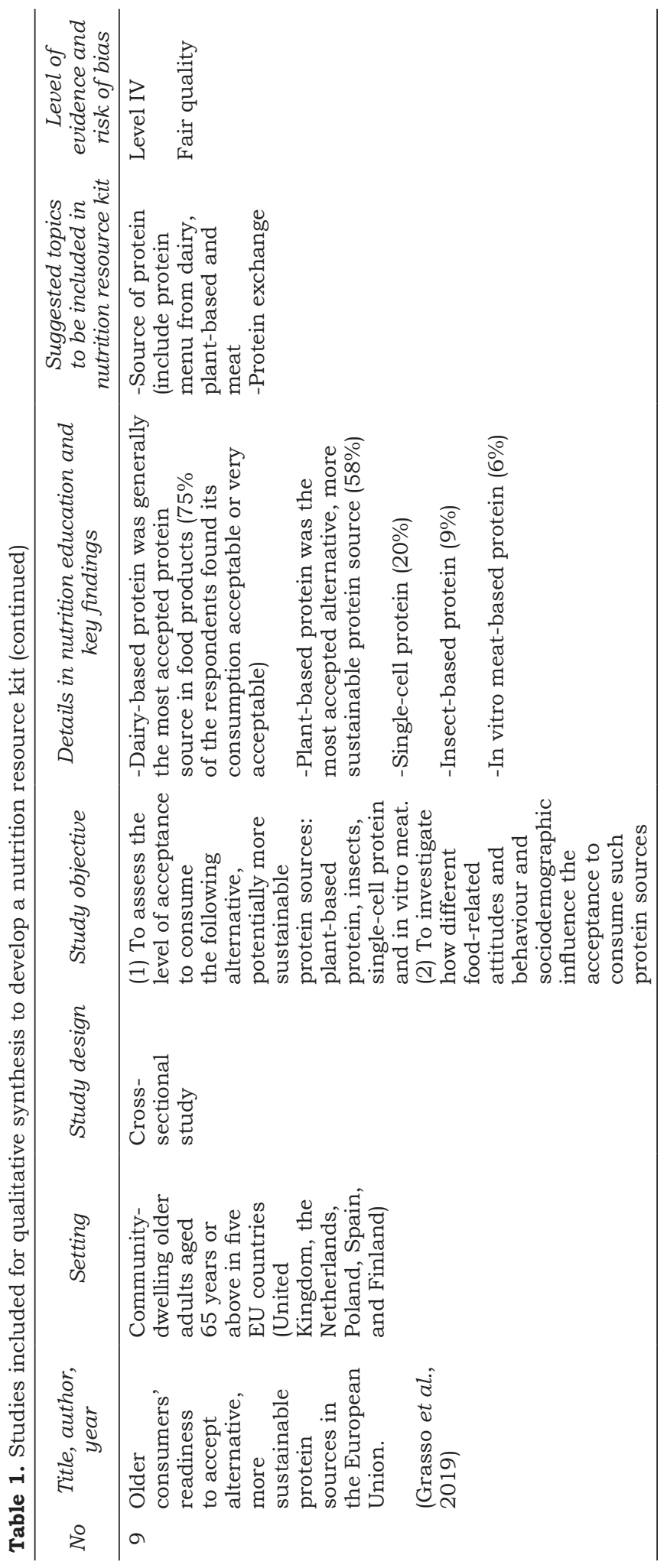




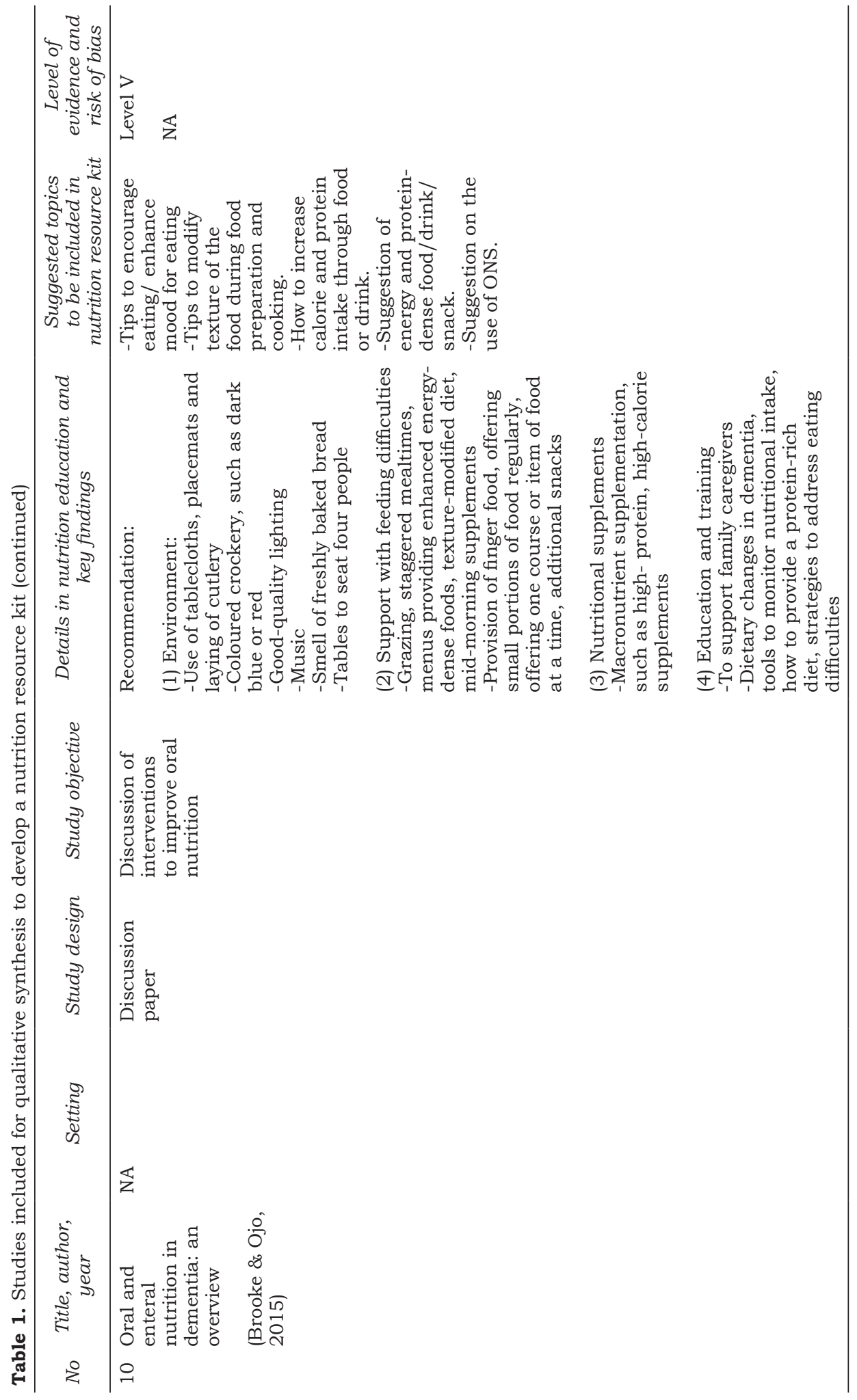




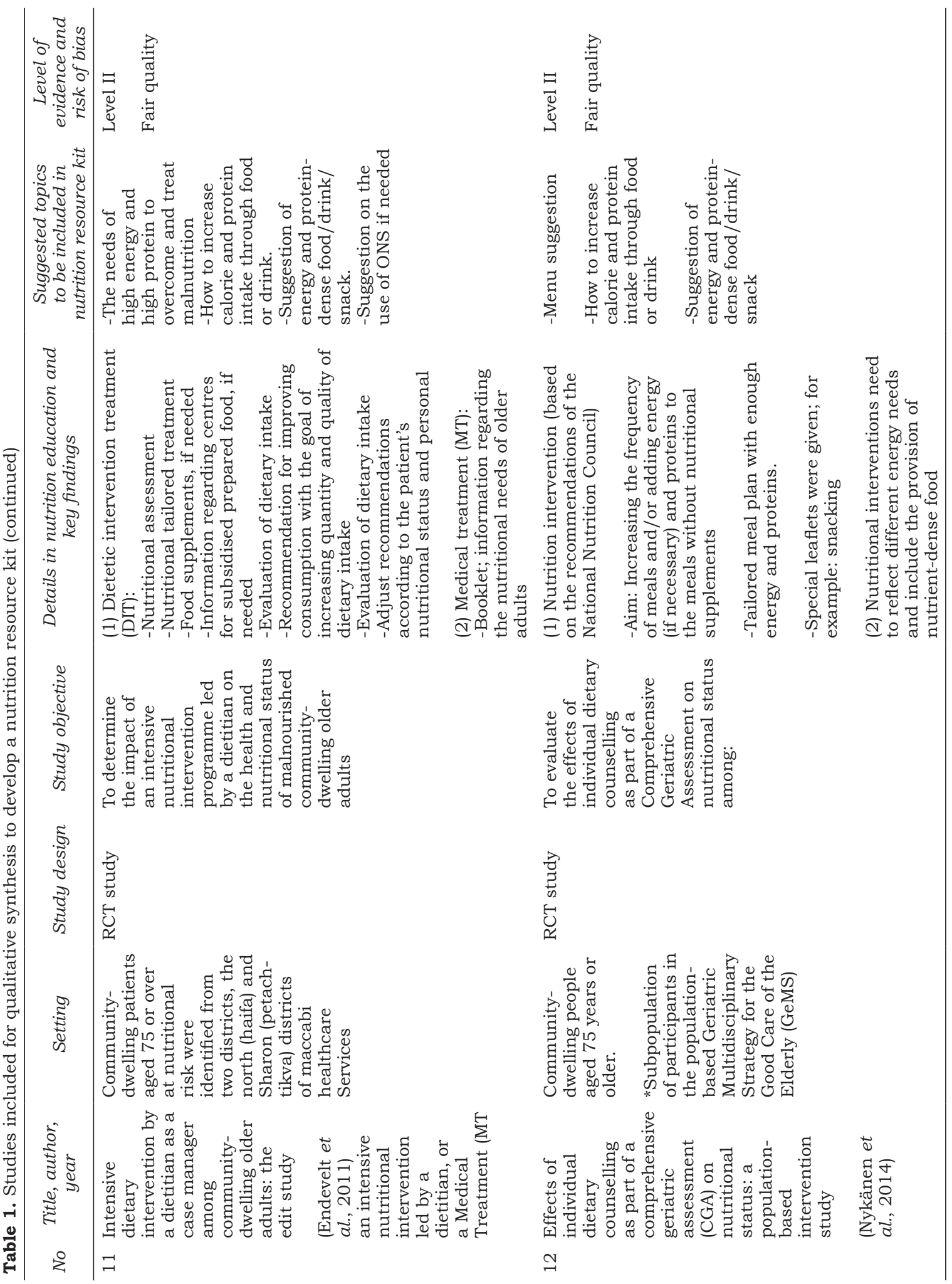




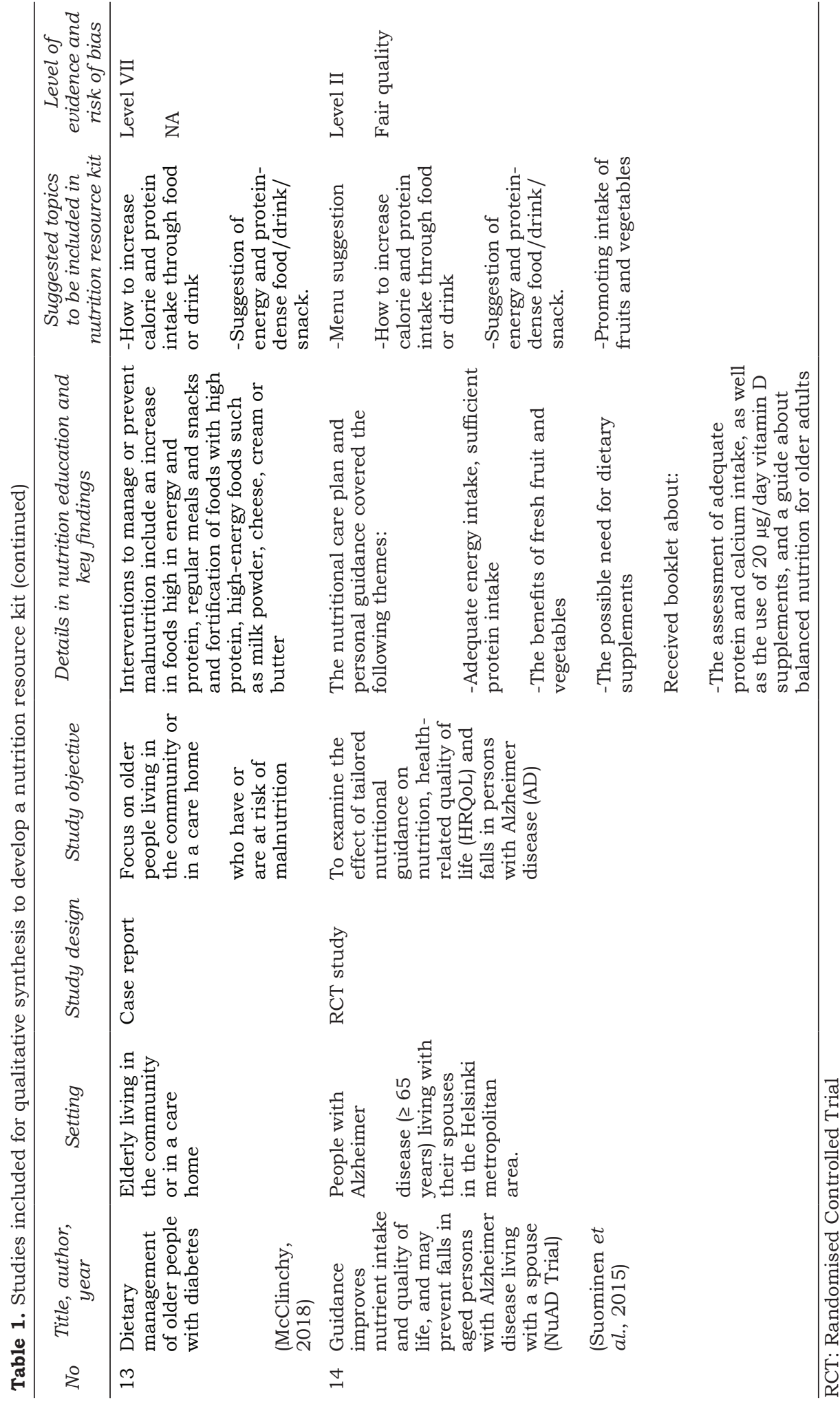




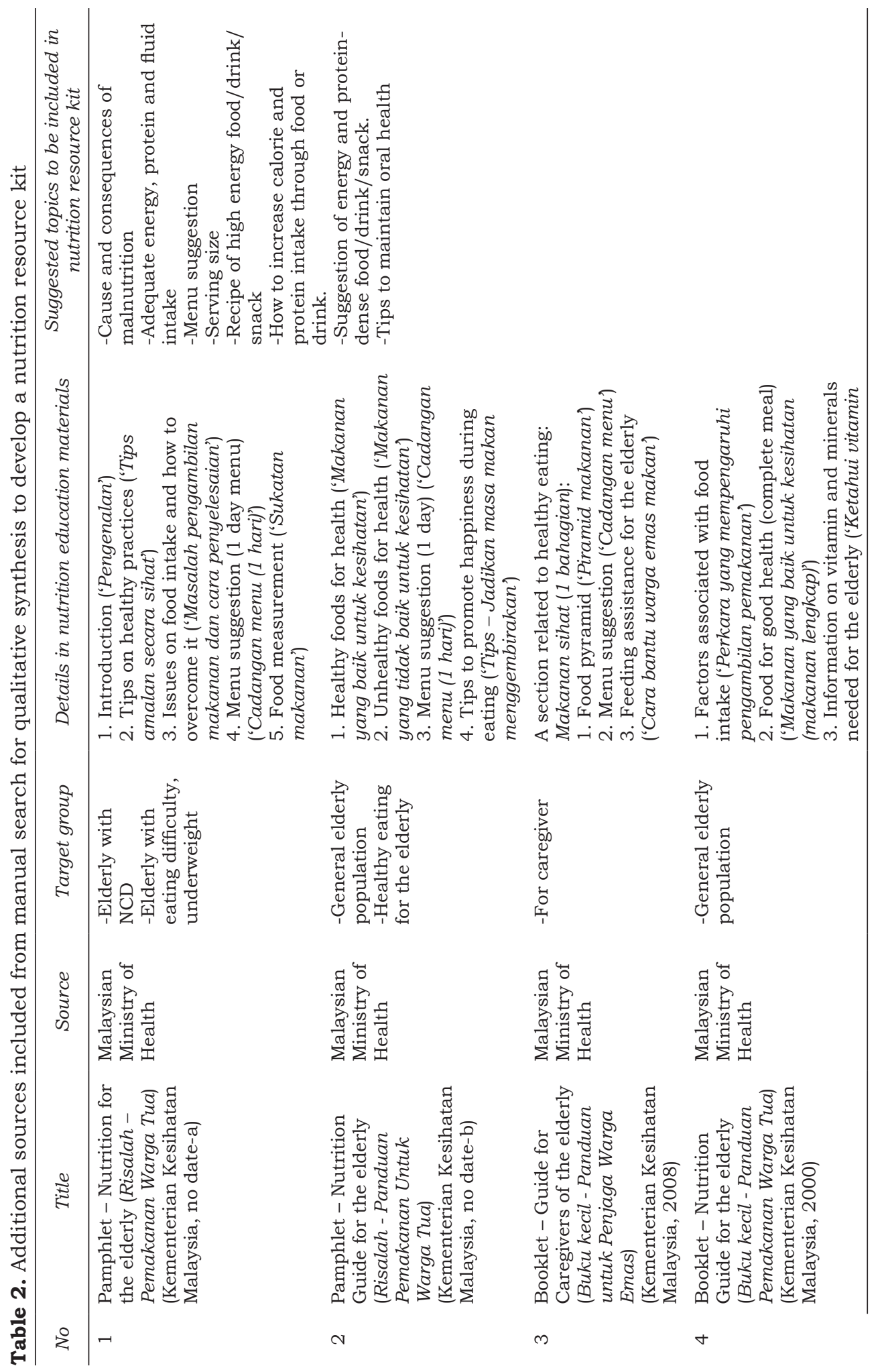



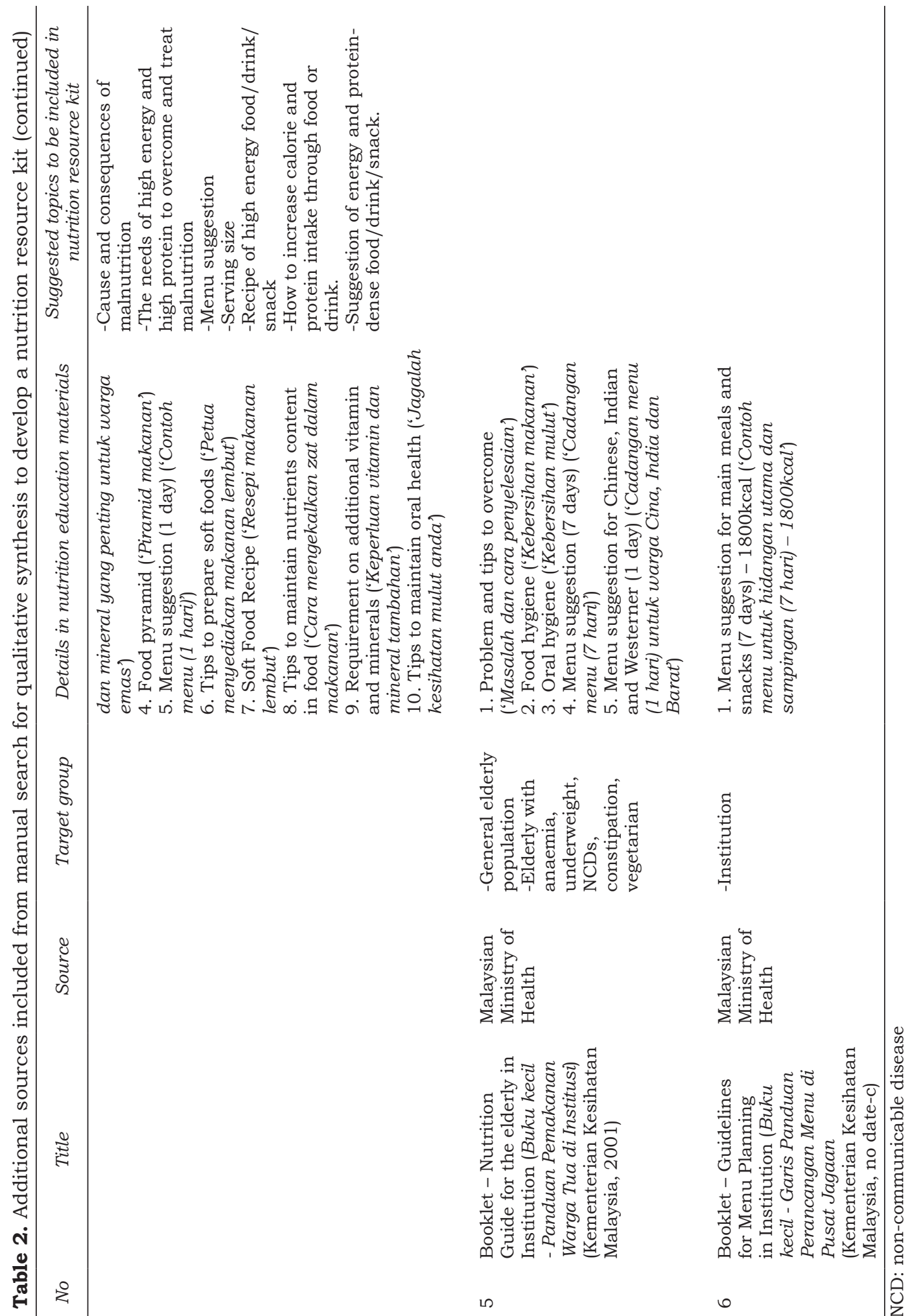


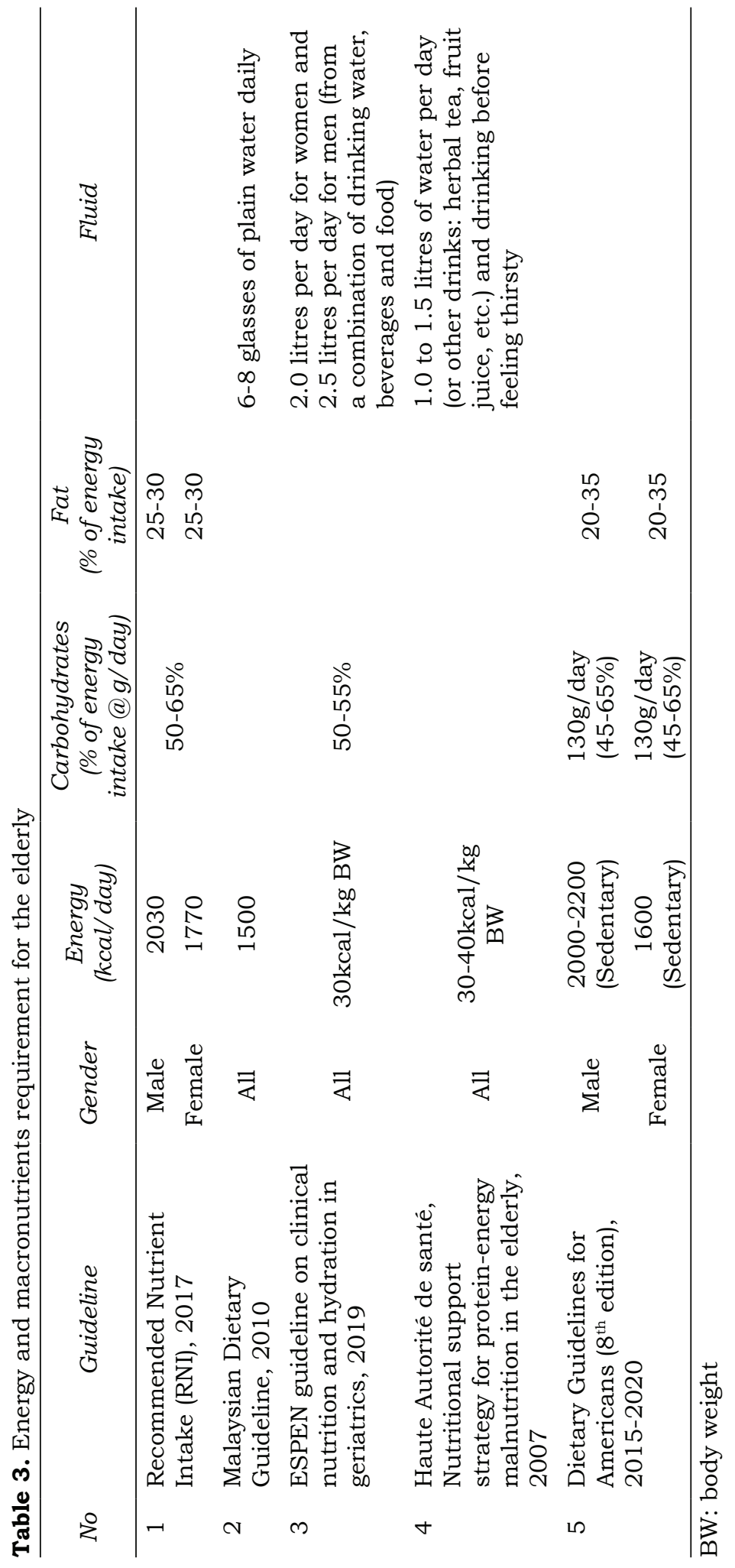


Table 4. Protein requirement for malnourished elderly

\begin{tabular}{cll}
\hline No & \multicolumn{1}{c}{ Source } & \multicolumn{1}{c}{ Protein Requirement } \\
\hline 1 & $\begin{array}{l}\text { ESPEN guideline on clinical nutrition } \\
\text { and hydration in geriatrics, 2019 }\end{array}$ & $1.2-1.5 \mathrm{~g} / \mathrm{kg} \mathrm{BW}$ and up to $2.0 \mathrm{~g} / \mathrm{kg} \mathrm{BW}$ \\
2 & $\begin{array}{l}\text { Haute Autorité de santé, Nutritional } \\
\text { support strategy for protein-energy } \\
\text { malnutrition in the elderly, 2007 }\end{array}$ & $1.2-1.5 \mathrm{~g} / \mathrm{kg} \mathrm{BW}$ \\
\hline
\end{tabular}

BW: body weight

Table 5. Summary of suitable topics to be included as content in nutrition resource kit

\begin{tabular}{|c|c|c|}
\hline No & Component & Suitable topics to be included in nutrition resource kit \\
\hline 1 & $\begin{array}{l}\text { Understanding on } \\
\text { malnutrition }\end{array}$ & $\begin{array}{ll}\text { - } & \text { Definition } \\
\text { - } & \text { Signs and symptoms } \\
\text { - Cause-consequences }\end{array}$ \\
\hline 2 & Malnutrition management & $\begin{array}{ll}\text { - } & \text { Food plate } \\
\text { - } & \text { Serving size }\end{array}$ \\
\hline 3 & $\begin{array}{l}\text { Implementation of } \\
\text { malnutrition management }\end{array}$ & $\begin{array}{ll}\text { - } & \text { Menu suggestion } \\
\text { - } & \text { Examples of recipes } \\
\text { Tips to increase energy and protein intakes } \\
\text { through food or drink } \\
\text { - } \quad \text { Texture modification } \\
\text { - Tips to maintain nutrients content in food and } \\
\text { drink } \\
\text { - Tips to encourage to eat } \\
\text { - Oral health }\end{array}$ \\
\hline
\end{tabular}

Nykänen et al., 2014; Shahar et al., 2012; Suominen et al., 2015; van Doorn-van Atten et al., 2018). Serving size was also mentioned (Francis et al., 2004; Shahar et al., 2012). In addition, several studies targeted on hydration status (Fernández-Barrés et al., 2017; Luger et al., 2016) or educational materials (Francis et al., 2004; Shahar et al., 2012). Most available educational materials and guidelines also provided information related to fluid requirement. The use of a plate to portray and deliver information was also mentioned in two studies (Luger et al., 2016; Shahar et al., 2012).

Implementing malnutrition management A few studies highlighted the possible methods to prevent and overcome malnutrition, such as texture adaptation and modification in food preparation and methods of cooking (Brooke \& Ojo, 2015; Fernández-Barrés et al., 2017; Zelig et al., 2019), recommended cooking methods (Fernández-Barrés et al., 2017), healthy cooking tips (Francis et al., 2004), menu suggestion (Brooke \& Ojo, 2015; Nykänen et al., 2014), and recipes for high energy and high protein menu (Luger et al., 2016). Other studies mentioned promoting energy and protein-rich foods (Brooke \& Ojo, 2015; Fernández-Barrés et al., 2017; MacNab et al., 2018; McClinchy, 2018; Nykänen et al., 2014) including food fortification and nutritional supplementation (Brooke \& Ojo, 2015; Endevelt et al., 2011; McClinchy, 2018; Suominen et al., 2015). Ways to control certain nutrients in foods 
and oral health were also mentioned in several studies and available educational materials. Information related to the implementation of malnutrition management are suggested to be included in the nutrition resource kit as this may guide the target population specifically on how to improve their nutritional status in their daily lives.

\section{DISCUSSION}

Malnutrition is linked to various adverse clinical outcomes, including prolonged hospitalisation due to longer time needed to recover, increased risk of complications, effect on the patient's recovery, and increased risk of morbidity and mortality (Correia \& Waitzberg, 2003). The health status of elderly is highly dependent on their nutritional risk. Wallace, Lo and Devine (2016) advocated the view that tailored nutrition education in elderly can lead to sustained dietary behaviour changes. Therefore, it is recommended to provide a nutrition resource kit to this target group in order to combat this issue. Previous systematic reviews concluded that nutrition education interventions might help improve malnutritionrelated outcomes in elderly populations. However, more studies are required to support this evidence (Rea, Walters \& Avgerinou, 2019).

This review is mainly to identify relevant topics for the content development of a nutrition resource kit for malnourished and at-risk elderly, with the purpose of providing nutritional knowledge and information for them to improve their dietary intake in order to overcome and prevent malnutrition. Suitable content identified through this review included information related to malnutrition such as definition, signs and symptoms, cause-consequences, and nutrition management, which included food plate, serving size, menu suggestion, examples of recipes, tips to increase energy and protein intakes through food or drink, texture modification, guide to using oral nutritional supplements, tips for maintaining nutrient content in food and drink, and oral health. The level of evidence among these research papers ranged from levels II to VII. All papers included in this review were of fair and good quality. All papers provided credibility to the body of knowledge.

Available printed versions of educational materials from the Ministry of Health, Malaysia, were also included in the manual search. However, it is worth noting that none of them were designed specifically for malnourished and atrisk elderly. Nevertheless, the details in these nutrition education materials were extracted to identify suitable content for the nutrition resource kit.

This nutrition resource kit will act as a guide to which malnourished and at-risk elderly would be able to refer to whenever needed. Even though the kit is mainly targeted for the elderly, participation of family members and caregivers would be beneficial as this would facilitate the use of this kit in the target group (Marshall \& Hale, 2017).

\section{Understanding malnutrition}

Information related to malnutrition is suitable for the kit (Fernández-Barrés et al., 2017; van Doorn-van Atten et al., 2018). This includes a brief explanation on the definition, signs and symptoms, and causes and consequences. The purpose of this information is to provide an overview of malnutrition to the elderly. Therefore, they will acquire general information and awareness about this issue. Besides, this general information primarily aims to enhance belief selection and consciousness, as well as to provide information on the consequences of behaviour (van Doornvan Atten et al., 2018). 


\section{Managing malnutrition}

The nutritional requirement of the elderly could differ considerably from other age groups due to the normal ageing process, medical condition or lifestyle. Generally, nutritional requirements, specifically energy and protein, are higher for the elderly at risk of malnutrition or are already malnourished. Therefore, a specific nutritional recommendation for this target group is needed to be incorporated in the nutrition resource kit according to any available and suitable dietary guidelines. Several studies highlighted the need for adequate fluid intake among the elderly (FernándezBarrés et al., 2017; Francis et al., 2004; Luger et al., 2016; Shahar et al., 2012), as inadequate fluid intake could contribute further to dehydration and affect the elderly's quality of life (Begum \& Johnson, 2010). Hence, information on fluid requirement needs to be considered as a content in the nutrition resource kit.

\section{Implementing malnutrition management}

In addition, information related to strategies to increase their daily energy and protein intakes should be incorporated into the kit. Most of the studies emphasised the need to include menu suggestion, examples of recipes, tips to increase energy and protein intakes through food or drink, texture modification, a guide to using oral nutritional supplements, and tips to maintain nutrients content in food and drink. Offering texture-modified, enriched foods for the elderly who are malnourished or at risk of malnutrition is a good practice to ensure adequate dietary intake among them (Volkert et al., 2019).

Several studies emphasised the use of food or nutritional supplements for malnourished and at-risk elderly
(Brooke \& Ojo, 2015; Endevelt et al., 2011; McClinchy, 2018; Suominen et al., 2015). Oral nutritional supplement (ONS) can be described as an energy and nutrient-dense product aimed at increasing one's dietary intake when diet alone is unable to meet the daily energy requirements of the elderly (Volkert et al., 2019). ONS can be categorised as standard ONS and disease-specific ONS. ONS are frequently recommended for those malnourished and at risk of malnutrition (Uí Dhuibhir, Collura \& Walsh, 2019). According to Parsons et al. (2017), the use of ONS is quite effective as one of the options to increase a person's oral dietary intake. Hence, a brief guide on the use of ONS that are commonly found in the Malaysian setting should be included in the kit. Additionally, instructions for elderly to get advice from a dietitian and nutritionist on the use of ONS should also be mentioned for accurate prescription on ONS intake upon referral by physician.

Information about oral health should be included as well in the nutrition resource kit (Zelig et al., 2019). Oral health is one of the contributing factors to malnutrition among the elderly. Oral health issues could reduce the ability of elderly to chew and eat, which directly leads to practical issues in the provision of adequate nutrition (Krishnamoorthy et al., 2018). A study conducted by Rosli et al. (2019) in Kuala Pilah, Malaysia, demonstrated that oral health-related quality of life was significantly associated with nutritional condition among the elderly participants. Therefore, it is important for the elderly to maintain their oral health in order to prevent and overcome malnutrition.

Furthermore, studies have aimed to develop nutrition education materials that suit not only the elderly population but also their caregivers (Francis et al., 2004) or healthcare professionals 
(Shahar et al., 2012). This has been demonstrated in 'Panduan untuk Penjaga Warga Emas', an educational material provided by the Ministry of Health, Malaysia, that is aimed to provide information for caregivers. Francis et al. (2004) also included caregivers as their target audience as they were required to be actively involved in healthcare delivery. Shahar et al. (2012) also developed a nutrition education package that healthcare professionals can use as a teaching tool. Nevertheless, this review is important as it identified suitable topics to be included in a nutrition resource kit. Thus, any suitable and relevant information to caregivers or healthcare staffs were extracted and included.

The strengths of this review were that it followed the PRISMA-ScR guidelines, and the data were checked and discussed among the researchers. This research nevertheless had its limitations. Since articles were limited to English and Malay languages only, other articles that might have provided relevant information to develop content for the nutrition resource kit were not included.

\section{CONCLUSION}

To conclude, this scoping review offered new insights into the content that can be included in the future development of a nutrition resource kit aimed at tackling malnutrition among the elderly in community settings. The content identified included information related to malnutrition such as definition, signs and symptoms, cause-consequences, and nutrition management, which included food plate, serving size, menu suggestion, examples of recipes, tips to increase energy and protein intakes through food or drink, texture modification, a guide to using oral nutritional supplements, tips to maintain nutrients content in food and drink, and tips to encourage to eat, and oral health. The topics identified can be incorporated into the kit in order to facilitate the elderly in improving their dietary intake. Therefore, a nutrition resource kit that provides nutritional guidance for malnourished and at-risk elderly can be useful for healthcare professionals as a nutrition intervention strategy. Further review could be performed in the future to measure its outcomes, particularly in providing nutrition education materials for the elderly to overcome malnutrition.

\section{Acknowledgement}

Funding for this study was received from the Fundamental Research Grant Scheme (FRGS), Ministry of Education, Malaysia (Reference number: FRGS/1/2018/SKK06/UIAM/02/5).

\section{Authors' contributions}

INNA, conducted the study, data analysis and interpretation, prepared the draft of the manuscript and reviewed the manuscript; $\mathrm{AHH}$, principal investigator, conceptualised and designed the study, contributed expertise, data analysis and interpretation, and reviewed the manuscript; $\mathrm{SH}$, contributed expertise and reviewed the manuscript; MAMA, contributed expertise and reviewed the manuscript; KHAA, contributed expertise and reviewed the manuscript; SNASH, contributed to data analysis and interpretation; NSAR, contributed expertise and reviewed the manuscript.

\section{Conflict of Interest}

The authors declare no conflict of interest.

\section{References}

Ackley BJ, Swan BA, Ladwig GB \& Tucker SJ (2008). Evidence-Based Nursing Care Guidelines: Medical-Surgical Interventions. St. Louis, Missouri: Mosby, Inc.

Ahmadzadeh Tori N, Shojaeizadeh D, Sum S \& Hajian K (2019). Effect of BASNEF-based nutrition education on nutritional behaviors among the elderly people and Mini Nutritional Assessment on nutritional status in elderly with diabetes with type 2 diabetes (A clinical trial intervention). J Educ Health Promot 8:94. https://doi.org/10.4103/jehp.jehp_222_18 
Begum MN \& Johnson CS (2010). A review of the literature on dehydration in the institutionalised elderly. E-SPEN, E Spen Eur E J Clin Nutr Metab 5(1): e47-e53. https:/ / doi. org/10.1016/j.eclnm.2009.10.007

Brooke J \& Ojo O (2015). Oral and enteral nutrition in dementia: an overview. $\mathrm{Br} J$ Nurs 24(12): 624-628. https://doi.org/10.12968/ bjon.2015.24.12.624

Cereda E, Pedrolli C, Klersy C, Bonardi C, Quarleri L, Cappello S, Turri A, Rondanelli M \& Caccialanza R (2016). Nutritional status in older persons according to healthcare setting: A systematic review and meta-analysis of prevalence data using MNA®. Clin Nutr 35(6):1282-1290. https://doi.org/10.1016/j. clnu.2016.03.008

Damião R, Santos ÁDS, Matijasevich A \& Menezes PR (2017). Factors associated with risk of malnutrition in the elderly in southeastern Brazil. Rev Bras Epidemiol 20(4):598610. https://doi.org/10.1590/19805497201700040004

Department of Statistics Malaysia (2019). Department Of Statistics Malaysia Press Release Current Population Estimates, Malaysia, 20182019.

Donini LM, Scardella P, Piombo L, Neri B, Asprino R, Proietti AR, Carcaterra S, Cava E, Cataldi S, Cucinotta D, Di Bella G, Barbagallo M \& Morrone A (2013). Malnutrition in elderly: social and economic determinants. $J$ Nutr Health Aging 17(1):9-15. https://doi.org/10.1007/ s12603-012-0374-8

Endevelt R, Lemberger J, Bregman J, Kowen G, Berger-Fecht I, Lander H, Karpati T \& Shahar DR (2011). Intensive dietary intervention by a dietitian as a case manager among community dwelling older adults: the EDIT study. $J$ Nutr Health Aging 15(8):624-630. https://doi. org/10.1007/s12603-011-0074-9

Fernández-Barrés S, García-Barco M, Basora J, Martinez T, Pedret R \& Arija V (2017). The efficacy of a nutrition education intervention to prevent risk of malnutrition for dependent elderly patients receiving Home Care: a randomised controlled trial. Int $J$ Nurs Stud 70:131-141. https://doi.org/10.1016/j. ijnurstu.2017.02.020

Francis SL, Taylor ML \& Strickland AW (2004). Needs and preference assessment for an inhome nutrition education program using Social Marketing Theory. Journal of Nutrition for the Elderly 24(2):73-92. https://doi.org/10.1300/ J052v24n02_07
Grasso AC, Hung Y, Olthof MR, Verbeke W \& Brouwer IA (2019). Older Consumers' Readiness to Accept Alternative, More Sustainable Protein Sources in the European Union. Nutrients 11(8):1904. https://doi. org/10.3390/nu11081904

Hamirudin AH, Charlton K, Walton K, Bonney A, Potter J, Milosavljevic M, Hodgkins A, Albert G, Ghosh A \& Dalley A (2014). Feasibility of implementing routine nutritional screening for older adults in Australian general practices: a mixed-methods study. BMC Family Practice 15:186. https://doi.org/10.1186/s12875014-0186-5

Higgins MM \& Barkley MC (2004). Improving Effectiveness of Nutrition Education Resources for Older Adults. Journal of Nutrition for the Elderly 23(3): 19-54. https://doi.org/10.1300/ J052v23n03

Kementerian Kesihatan Malaysia (no date-a). Pemakanan Warga Tua. Cawangan Pemakanan, Bahagian Pembangunan Kesihatan Keluarga, Kementerian Kesihatan Malaysia. From http:// fh.moh.gov.my/v3/index.php/component/ jdownloads/send/23-sektor-kesihatanwarga-emas / 499-pemakanan-warga-tuarisalah?Itemid=0 [Retrieved August 27 2019].

Kementerian Kesihatan Malaysia (no date-b). Panduan Pemakanan Untuk Warga Tua. Bahagian Pendidikan Kesihatan, Kementerian Kesihatan Malaysia. From https://www. infosihat.gov.my/multimedia/risalah / item/warga-tua-panduan-pemakanan.html [Retrieved August 27 2019].

Kementerian Kesihatan Malaysia (2008). Panduan Untuk Penjaga Warga Emas. Bahagian Pembangunan Kesihatan Keluarga, Kementerian Kesihatan Malaysia. From https://www.infosihat.gov.my/index.php/ multimedia/buku-kecil/item/panduanuntuk-penjaga-warga-emas [Retrieved August 27 2019].

Kementerian Kesihatan Malaysia (2000). Panduan Pemakanan Warga Tua. Bahagian Pendidikan Kesihatan, Kementerian Kesihatan Malaysia From https://www.infosihat.gov. my/multimedia/buku-kecil/item/panduanpemakanan-warga-emas.html August 27 2019].

[Retrieved

Kementerian Kesihatan Malaysia (2001). Panduan Pemakanan Warga Tua di Institusi. Cawangan Pemakanan, Bahagian Pembangunan Kesihatan Keluarga, Kementerian Kesihatan Malaysia. From http://fh.moh.gov.my/v3/ index.php/pages/orang-awam/kesihatanwarga-emas-1. [Retrieved August 27 2019]. 
Kementerian Kesihatan Malaysia (no date-c). Garis Panduan Perancangan Menu di Pusat Jagaan. Bahagian Pemakanan, Kementerian Kesihatan Malaysia. From http://nutrition. moh.gov.my/buku [Retrieved August 27 2019].

Krishnamoorthy Y, Vijayageetha M, Kumar SG, Rajaa S \& Rehman T (2018). Prevalence of malnutrition and its associated factors among the elderly population in rural Puducherry using mini - nutritional assessment questionnaire. $J$ Family Med Prim Care 7(6):1429-1433. https: / / doi.org/10.4103/jfmpc.jfmpc_22_18

Luger E, Dorner TE, Haider S, Kapan A, Lackinger C \& Schindler K (2016). Effects of a homebased and volunteer-administered physical training, nutritional, and social support program on malnutrition and frailty in older persons: A randomized controlled trial. $\mathrm{J} \mathrm{Am}$ Med Dir Assoc 17(7):671.e9-671.e16. https:// doi.org/10.1016/j.jamda.2016.04.018

MacNab L, Francis SL, Lofgren I, Violette C, Shelley MC, Delmonico M \& Xu F (2018). Factors influencing dietary intake frequencies and nutritional risk among community-residing older adults. J Nutr Gerontol Geriatr 37(34):255-268. https://doi.org/10.1080/215511 97.2018.1524809

Mafauzy M (2000). The problems and challenges of the aging population of Malaysia. Malaysian Journal of Medical Sciences 7(1):1-3. From http://www.ncbi.nlm.nih. gov/pubmed/22844207\%0Ahttp: / / www. pubmedcentral.nih.gov/articlerender. fcgi?artid=PMC3406209 [Retrieved February 12 2020].

Mann T, Heuberger R \& Wong, H (2013). The association between chewing and swallowing difficulties and nutritional status in older adults. Aust Dent J 58(2):200-206. https: / / doi. org/10.1111/adj.12064

Marshall K \& Hale D (2017). Caregiver education and support. Home Healthc Now 35(6):341-342. https://doi.org/10.1097/ NHH.0000000000000554

McClinchy J (2018). Dietary management of older people with diabetes. $\mathrm{Br} J$ Community Nurs 23:248-251.

NCCFN (2010). Malaysian Dietary Guidelines. National Coordinating Committee on Food and Nutrition, Ministry of Health Malaysia, Putrajaya.

NCCFN (2017). Recommended Nutrient Intakes for Malaysia. A Report of The Technical Working Group on Nutritional Guidelines. National Coordinating Committee on Food and Nutrition, Ministry of Health Malaysia, Putrajaya.
Nur Fazimah S, Sakinah H \& Rosminah M (2013). Hospitalised geriatric malnutrition: A perspective of prevalence, identification and implications to patient and healthcare cost. Health Environ $J$ 4(1):55-67. Retrieved from https://pdfs.semanticscholar. org/2adb/ 57651a660017f86c818e7daa18e853964ac4. pdf

Nykänen I, Rissanen TH, Sulkava R \& Hartikainen $S$ (2014). Effects of individual dietary counseling as part of a comprehensive geriatric assessment (CGA) on nutritional status: a population-based intervention study. $J$ Nutr Health Aging 18(1):54-58. https://doi. org/10.1007/s12603-013-0342-y

Parsons EL, Stratton RJ, Cawood AL, Smith TR \& Elia M (2017). Oral nutritional supplements in a randomised trial are more effective than dietary advice at improving quality of life in malnourished care home residents. Clin Nutri 36(1):134-142. https://doi.org/10.1016/j. clnu.2016.01.002

Rea J, Walters K \& Avgerinou C (2019). How effective is nutrition education aiming to prevent or treat malnutrition in community-dwelling older adults? A systematic review. Eur Geriatr Med 10:339-358. https://doi.org/10.1007/ s41999-019-00172-6

Rosli TI, Chan YM, Kadir RA \& Hamid TAA (2019). Association between oral health-related quality of life and nutritional status among older adults in district of Kuala Pilah, Malaysia. BMC Public Health 19(Suppl 4): 547. https://doi. org/10.1186/s 12889-019-6867-1

Schoberer D, Eglseer D, Halfens RJG \& Lohrmann C (2018). Development and evaluation of brochures for fall prevention education created to empower nursing home residents and family members. Int J Older People Nurs 13(2):e12187. https://doi.org/10.1111/opn.12187

Shahar S, Adznam SN, Rahman SA, Yusoff NAM, Yassin Z, Arshad F, Sakian NI, Salleh M \& Samah AA (2012). Development and analysis of acceptance of a nutrition education package among a rural elderly population: an action research study. BMC Geriatr 12:24. https:// doi.org/doi:10.1186/1471-2318-12-24

Stratton RJ \& Elia M (2010). Encouraging appropriate, evidence-based use of oral nutritional supplements. Proc Nutr Soc 69(4):477-487. https://doi.org/10.1017/ S0029665110001977 
Suominen MH, Puranen TM, Jyväkorpi SK, Eloniemi-Sulkava U, Kautiainen H, SiljamäkiOjansuu U \& Pitkalä KH (2015). Nutritional guidance improves nutrient intake and quality of life, and may prevent falls in aged persons with alzheimer disease living with a spouse (NuAD Trial). JNutr Health Aging 19(9):901-907. https://doi.org/10.1007/s12603-015-0558-0

Uí Dhuibhir P, Collura N \& Walsh D (2019). Complete oral nutritional supplements: Dietitian preferences and clinical practice $J$ Diet Suppl 16(1):40-50. https://doi.org/10.10 80/19390211.2018.1428260

United Nations (2017). World Population Prospects: The 2017 Revision, Key findings \& Advance Tables. Department of Economic and Social Affairs, Population Division, United Nations. Retrieved from Working Paper No. ESA/P/ $\mathrm{WP} / 248$

Van Bokhorst-de van der Schueren MAE, Lonterman-Monasch S, de Vries, OJ, Danner SA, Kramer, MHH \& Muller M (2013). Prevalence and determinants for malnutrition in geriatric outpatients. Clin Nutr 32(6)1007-1011. https://doi.org/10.1016/j.clnu.2013.05.007

van Doorn-van Atten MN, Haveman-Nies A, Pilichowski P, Roca R, De Vries JHM \& De Groot CPGM (2018). Telemonitoring to improve nutritional status in community-dwelling elderly: design and methods for process and effect evaluation of a non-randomised controlled trial. BMC Geriatr 18(1):284. https://doi.org/10.1186/s 12877-018-0973-2

van Doorn-van Atten MN, Haveman-Nies A, van Bakel MM, Ferry M, Franco M, de Groot LCPGM \& de Vries JHM (2018). Effects of a multi-component nutritional telemonitoring intervention on nutritional status, diet quality, physical functioning and quality of life of community-dwelling older adults. $\mathrm{Br} \mathrm{J}$ Nutr 119(10):1185-1194. https://doi.org/10.1017/ S0007114518000843
Vassar M, Atakpo P \& Kash MJ (2016). Manual search approaches used by systematic reviewers in dermatology. $J$ Med Libr Assoc 104(4):302-304. https://doi. org/ 10.3163/1536-5050.104.4.009

Volkert D, Beck AM, Cederholm T, Cereda E, CruzJentoft A, Goisser S, de Groot L, Grobßhauser F, Kiesswetter E, Norman K, POurhassan M, Reinders I, Roberts HC, Rolland Y, Schneider SM, Sieber CC, Thiem U, Visser M, Wijnhoven HAH \& Wirth R (2019). Management of malnutrition in older patients-Current approaches, evidence and open questions. $J$ Clin Med 8(7):974. https://doi.org/10.3390/ jcm8070974

Volkert D, Beck AM, Cederholm T, Cruz-Jentoft A, Goisser S, Hooper L, Kiesswetter E, Maggio M, Raynaud-Simon A, Sieber CC, Sobotka L, van Asselt D, Wirth R \& Bischoff SC (2019). ESPEN guideline on clinical nutrition and hydration in geriatrics. Clin Nutr 38(1):10-47. https://doi. org/10.1016/j.clnu.2018.05.024

Wallace R, Lo J \& Devine A (2016). Tailored nutrition education in the elderly can lead to sustained dietary behaviour change. $J$ Nutr Health Aging, 20(1):8-15. https://doi.org/10.1007/s12603015-0529-5

Yahya HM, Z NAA, Shahar S \& KA Singh D (2020). Development and evaluation of a booklet on nutrition education for falls prevention among older adults. Jurnal Sains Kesihatan Malaysia 18(2):9-17. https://doi.org/10.17576/jskm2020-1802-02

Zelig R, Jones VM, Touger-Decker R, Hoskin ER, Singer SR, Byham-Gray L, Radler DR \& Rothpletz-Puglia P (2019). The eating experience: Adaptive and maladaptive strategies of older adults with tooth loss. JDR Clin Trans Res 4(3):217-228. https://doi. org/ 10.1177/2380084419827532 